\author{
Проф. др ЖАРКО ПЕТКОВИЋ \\ Универзитет у Београду \\ Филозофски факултет, Одељење за историју \\ Чика Љубина 18-20, Београд, Србија \\ zarkopetkovic@gmail.com
}

\title{
МАРИЈЕВА ПОСТУМНА ПОПУЛАРНОСТ
}

САЖЕТАК: УГлавном се у литератури сматра да је популарски покрет, без обзира на пораз у Грађанском рату, морао имати своје присталице у Риму током седамдесетих година. Но, једно је био популарски покрет, а друго је била успомена на политику Гаја Марија. Одсуство сведочанстава да је јавно сећање на Марија уопште било присутно све до Цезаровог едилитета, као и рђаве оцене Маријевог карактера у мемоарској и историографској литератури, воде закључку да је успомена на великог војсковођу, вођу популара и спаситеља отаџбине, заправо била обликована захваљујући Цезару и Цицерону, односно њиховим политичким и личним интересима из шездесетих и педесетих година. Пост-Сулин режим није наметао формалне забране, али међу популарима те генерације морао је остати утисак да је Марије био издајица њиховог покрета, као и да је био непотребно суров у Грађанском рату. Такав претежни утисак оставио је трага на (Цицероново) беседништво, али и на римску историографију и мемоарску књижевност.

КљУЧНЕ РЕЧИ: крај Римске Републике, Гај Марије, Гај Јулије Цезар, Марко Тулије Цицерон, популари, римска републиканска историографија

Новија историографија је недовољно заинтересована за биографије, упозоравао је један од највећих историчара прошлог века. ${ }^{1}$ Разлог за занемаривање ове дисциплине треба потражити пре свега у схватању да претерана

${ }^{1}$ E. g. A. Momigliano, Pagine ebraiche, Turin 1987, xxix-хxхі. Упор. Т. Cornell, "Momigliano and Biography", y: The Legacy of Arnaldo Momigliano (ed. T. Cornell, O. Murray), London-Turin 2014, 179-195; idem, "Introduction", y: A. D. Momigliano, Studies in Modern Scholarship (ed. G. W. Bowersock, T. Cornell), Berkeley - Los Angeles - London 1994, vii-ix; G. W. Bowersock, "Momigliano's Quest for the Person", y: The Presence of the Historian. Essays in Memory of Arnoldo Momigliano, History and Theory 30-4 (1991), 27-36. - Извори су цитирани у складу са трећим издањем The Oxford Classical Dictionary, док се разрешење скраћеница часописа и референтне литературе може наћи у L'année philologique. - Сва датовања у овом раду дата су по ери пре Христа. 
психологизација постаје сама себи циљ и да, притом, не може дати егзактне одговоре, каквима тежи модеран човек. Уз то, биографији као историографској подврсти није погодовало раширено схватање да просопографија није њена помоћна дисциплина, већ самостални и самодовољни аналитички метод. Тако осамостаљена просопографија - поред изванредних резултата које пружа - не доприноси довољно упознавању изванредних појединаца и, следствено, не доприноси у пуној мери разумевању историје коју су ти истакнути људи стварали.

Међутим, оваква употреба просопографије није претежни разлог зашто је Гај Марије једна од најслабије познатих личности од свих великих државника позне Републике. ${ }^{2}$ Оскудном познавању Маријеве личности допринела je његова novitas, као и педагошки једноставна слика о славном војсковођи, спаситељу отаџбине, вођи плебса, који је временом, вођен личном амбицијом, издао покрет на чијем је челу стајао, а потом учествовао у Грађанском рату у којем је окрвавио руке. Можда и наведена оцена о његовој издаји није погрешна, колико год била опасно једносмерена. Слика о Марију, чије су врлине биле надвладане његовим амбицијама и гордошћу, могла би се односити на већину Плутархових јунака.

Тако је Томас Карни сматрао да је Марије био “ambitious and self centered”, завршавајући своју важну књигу закључком да личност, па ни контроверзни политички карактер, не би били довољни да објасне поштовање које је његово име и политичко достигнуће заслужило у наредним генерацијама. ${ }^{3}$ Овај текст ће се бавити управо питањем Маријеве постумне популарности.

I. За почетак, испитаћемо слику о Гају Марију која је створена у римским историографским и аутобиографским списима. У биографији Гаја Марија Плутарх се служио Мемоарима његовог архинепријатеља диктатора Суле, ${ }^{4}$ као и аутобиографијама његових противника Квинта Лутација Катула и Публија Рутилија Руфа. 5 По једној ауторитетној оцени, Плутархова биографија Марија представља један крпеж од материјала потеклог од ове тројице писаца. 6 Уз то, Посидоније, чије је дело Плутарх добро познавао и користио,

2 Додуше, о Марију имамо један просопографски податак који нам недостаје и за Помпеја, Краса и Сулу: упор. Е. Badian, Lucius Sulla. Deadly reformer, The Seventh Todd Memorial Lecture delivered in the University of Sidney 11 th September 1969, Sidney 1970, 6.

3 T. F. Carney, A Biography of C. Marius, Chicago 1970, 71-72.

${ }^{4}$ E. Valgiglio, "L'autobiografia di Silla nelle biografie di Plutarco", Studi Urbinati 49.1 (1975), 245-251; M. Chassignet, "Introduction", y: L'annalistique Romaine (texte établi et traduit M. Chassignet), III: L'annalistique Récente. L'autobiographie Politique (Fragments), Paris 2004, civ; Chr. Smith, "L. Cornelius Sulla", y: T. J. Cornell (gen. ed.), The Fragments of Roman Historians, I, Oxford 2013, 284-285.

5 Поред Сулиних Усйомена, Плутарх је користио Мемоаре Лутација Катула, Маријевог ривала: Chr. Smith, „Q. Lutatius Catulus”, у: The Fragments of Roman Historians, (нап. 4), 273; о њиховом личном непријатељству (inimicitia) видети сведочанства која наводи Fr. Münzer, $R E$ 13.2, 1927, 2079, а нарочито Plut. Mar. 25.8 (= Q. Lutatius Catulus, F 1 Peter, Cornell). Такође, Маријев лични непријатељ био је и Публије Рутилије Руф: Plut. Mar. 28.8; уосталом, Марије је учествовао у судском прогону Рутилија Руфа 92. године (Dio, fr. 97.3), тако да објективан однос према Марију не би било могуће очекивати у Руфовим историографским делима: упор. E. Badian, "Caepio and Norbanus", y: Studies in Greek and Roman History, Oxford 1963, 39 [= Historia 6-3 (1957), 324]; Chr. Smith, "P. Rutilius Rufus. Commentary", y: The Fragments of Roman Historians (нап. 4), 287.

${ }^{6}$ T. F. Carney, "Plutarch's Style in the Marius", JHS 80 (1960) 27-28. 
није повољно судио о карактеру Гаја Марија, ${ }^{7}$ ако је заиста закључни део Плутарховог Марија потекао од овог писца. ${ }^{8}$ Како год, Плутарх је заиста имао разлога да буде незадовољан изворима које је имао на располагању за биографију Гаја Марија. ${ }^{9}$ Било је неизбежно да слика о великом војсковођи буде обојена сведочанствима његових личних непријатеља.

Ни друге историографске списе нису саставили Маријеви пријатељи. Политичку аутобиографију Марка Емилија Скаура, ${ }^{10}$ по Цицероновим речима, нико није ни читао, ${ }^{11}$ а и да је нешто од њеног садржаја продрло, макар и посредно, до Плутарха, били би то, изгледа, неповољни искази о Гају Марију. ${ }^{12}$ Ни Салустије Крисп није био Маријев присталица; ${ }^{13}$ притом, његов

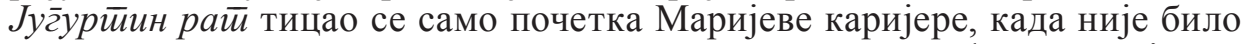
разлога за педагошку критику. На основу Периоха, као и формулација код Еутропија, Орозија, Јулија Обсеквенса и Флора, сме се закључити да Ливије није био наклоњен вођи странке популара, чак - очекивано - критичан, нарочито према његовим поступцима пред смрт. ${ }^{14}$ Та ливијевска критика кључно је утицала на Луканове стихове у којима преовлађују теме као што су Маријева ambitio и, при крају живота, dominatio и crudelitas..$^{15}$ Ни Велеј Патеркул нема добрих речи за Марија. ${ }^{16}$ Апијан је сматрао да је Марије сносио одговорност за избијање Грађанског рата, критиковао његове манипулације у додели команде за рат против Митридата;17 дакле, Апијан је био под ути-

${ }^{7}$ Plut. Mar. 45.3-7 = Pos. F 255 EK; Plut. Mar. 1.1-5 = Pos. F 264 EК. Упор. J. Malitz, Die Historien des Posidonius, München, 1983, 208-210, 224-228; D. A. Russell, Plutarch, LondonNew York 1972, 132; Jacoby, FrGrHist IIc, Komm, nr. 87, 158.8-10.

8 Мислим да I. G. Kidd (Posidonius. Vol. II. The Commentary (ii) Fragments 150-293, Cambridge 1988, 891-892) има право када каже да се једино поуздано може тврдити да од Посидонија потиче један детаљ (да је Марије био болестан од запаљења плућне марамице), иако постоје јаки аргументи у корист закључка да читав одељак (45.3-7) треба приписати овом филозофу (видети литературу у претходној напомени и Kidd, o.c, 890).

${ }_{9}^{9}$ Plut. Mar. 26.3: Сула; 26.5: Лутације Катул; 28.5: Рутилије Руф.

10 Tac. Agr. 1.1-2; упор. Chassignet (нап. 4), lxxxvi-lxxxvii.

11 Cic. Brut. 112.

12 Cic. Off. 1.76; Prov. Cons. 9; упор. J. van Ooetghem, Caius Marius, Bruxelles 1964, 11-12.

13 R. Syme, Sallust, Barkeley-Los Angeles 1964, 161-164; упор. нпр. 157, о Југуурииином pā̄y: Marius is prominent on show, but not magnified unduly; D. C. Earl, Political Thought of Sallust, Cambridge 1961, 74; 81.

${ }^{14}$ Liv. Per. 69: Marius ... seditionis auctor; Per. 80: Marius ... quam rem publicam armatus servavit, eam primo togatus omni genere fraudis, postremo armis hostiliter; Flor. 2.4; 2.9: Initium et causa belli inexplebilis honorum Marii fames...; Obs. 56a: Cinna et Mario per bella civilia crudeliter saevientibus Romae; Eutrop. 5.7.3; Oros. 5.17.6; Видети: D. S. Levene, "Three reading of character in the Periochae of Livy", y: Fame and Infamy: Essays for Christopher Pelling on Characterization in Greek and Roman Biography and Historiography, edd. R. Ash, J. Mossman, J. B. Titchener, Oxford 2018, 315. Такође, С. H. Lange, F. J. Vervaet, "Sulla and Origins of the Concept of Bellum Civile", y: The Historiography of Late Republican Civil War, edd. C. H. Lange, F. J. Vervaet, Leiden-Boston, 2018, 20-21; из истог зборника видети и T. Berge, "Epitomizing Discord: Florus on the late Republican Civil Wars", 429, као и D. Hoyos, "Livy on the Civil Wars (and After): Morality Lost?", 220-221.

${ }^{15}$ Lucan. 2.68-133; упор. M. P. O. Morford, "Lucan and the Marian Tradition”, Latomus 25/1 (1966) 109-114.

16 Vell. Pat. 2.11.1: ... C. Marius, quem praediximus, natus agresti loco, hirtus atque horridus vitaque sanctus, quantum bello optimus, tantum pace pessimus, immodicus gloriae, insatiabilis, impotens semperque inquietus.

${ }^{17}$ App. Praef. 14; BCiv. 1.55. Упор. Е. Badian, “The Death of Saturninus”, Chiron 14 (1984), 109. 
цајем непријатељских извора према Марију, и то, рекло би се, ливијевске традиције. Дион Касије писао је о Марију као о бунтовном човеку, пријатељу гомиле, чији је циљ био да се обрачуна са читавим нобилитетом. ${ }^{18}$ Диодор је наглашавао Маријеву кривицу за Грађански рат, његов морални пад, као и суровост према непријатељима, ${ }^{19}$ колико се може судити на основу спорадично сачуваног текста. Изузетак је Валерије Максим, који бележи низ примера који Марија осликавају у повољном светлу, али и код њега постоје критичко-морализаторски осврти на личност великог војсковође. ${ }^{20}$

II. Што се тиче питања да ли је успомена на Марија била жива након његове смрти у јавном животу, може се рећи да је она, у време Сулине диктатуре и десетак година након диктаторове смрти, иако вероватно није била подвргнута званичној забрани, ${ }^{21}$ била потиснута, непожељна и ризична. Плутарх сматра да је то време маријевска странка била у веома јадном стању, заплашена и распуштена; 22 штавише, још у време када је Цина повео рат против Октавија

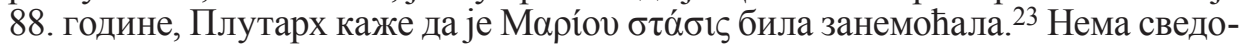
чанстава о томе да је успомена на Марија уопште живела током седамдесетих година. После завршетка Грађанског рата Серторије је покушавао, по Плутарховом сведочанству, да се дистанцира од недавних зверстава, посебно оних које је Марије починио, а претходно није са ентузијазмом прихватио Маријеву помоћ, тј. његов повратак из егзила. ${ }^{24}$ Ниједан писац не каже да се Лепид икада позвао на Гаја Марија, иако је у борби против Сулиног наслеђа као конзул повео прави Грађански рат у Етрурији, маријевском упоришту. ${ }^{25}$ Приметно је да ни при крају овог периода постепено напуштање Сулиног поретка и успон нових интересних група нису оживели успомену на Марија, нити се популарска или протопопуларска политика везивала за њега. Помпејева дистанцираност према успомени и наслеђу Гаја Марија била је знаковита.

Међутим, временом, ствари су се почеле мењати у јавном животу. Квестор Гај Јулије Цезар, ${ }^{26}$ приликом сахране сопствене тетке, приказао је Маријеву imago, ${ }^{27}$ а четири године касније, у време свог едилитета, обновио је Маријеве

18 Dio, fr. 89.2; 102.2. Упор. F. Millar, A Study of Cassius Dio, Oxford 1964, 79.

${ }^{19}$ Diod. 37.29.2-4; 38.4.1-3; 6.1.

20 Упор. Т. F. Carney, "The Picture of Marius in Valerius Maximus", RhM 105.4(1962) 289-337. Ипак, Валерије Максим је користио повремено извор(е) који је (су) наглашавао/-ли Маријеву суровост (e.g. 2.8.7; 9.2.2) или текстове који су осуђивали Марија због осветољубивости и немилосрдности које су одвеле Катула у смрт $(2.22 .4 ; 9.12 .4)$.

${ }^{21}$ Видети доле, нап. 33. Али, Сула је ускратио Марију сахрану (Сic. Leg. 2.56), тj. cy milites inimici (Сулини ветерани?) ископали су Маријев гроб и рашчеречили његов леш (Lic. 32F).

22 Plut. Caes. 6.1.

23 Plut. Ser. 4.7.

24 Plut. Ser. 5.6-7; 5.1; упор. Konrad, Plutarch's Sertorius. A Historical Commentary, Chapel Hill - London 1994, 66-72.

25 Упор. Sources for Roman History 133-70, ed. A. H. J. Greenidge/ A. M. Clay, rev. E. W. Gray, Oxford $1986^{2}, 232-235$.

26 За датовање види: L. Ross Taylor, Caesar's Early Career, CPh 36(1941), 122-124; упор. Broughton, MRR, III, 105-106.

27 Plut. Caes. 5.2-3. Плутарх је у овом сегменту Цезарове биографије користио спис(е?) Гаја Опија (Chr. Smith, T. Cornell, “C. Oppius”, у: The Fragments of Roman Historian [нап. 4], 382), Цезаровог пријатеља, што утврђује утисак да је „маријанизам”, између осталог, био Цезаров пропагандни курс; упор. Chr. Pelling, Plutarch. Caesar (transl., introduct., comm.) Oxford 2011, 50. 
споменике, и то уз статуе богиње победе. ${ }^{28}$ Вреди нагласити да је Цезар овим наставио политички курс свог деде и оца, који су се везали за Гаја Марија. ${ }^{29}$ Што се тиче манифестације на сахрани, у питању је, сматра се, Цезарово величање сопствених предака и рођака, као и испланирана популарска, антиоптиматска пропаганда. ${ }^{30}$ Питање је, међутим, да ли се ради у пуном смислу о маријевској манифестацији - у комисији за доделу земље ветеранима 103. године (дакле, махом онима који су под Маријем служили) учествовао је Цезаров отац, ${ }^{31}$ тако да њихово присуство на једној јулијевској сахрани нема искључиво маријевски смисао.

Ипак, успомена на Марија - потиснута и приватна - опстала је скривена од јавности, а Цезар је успео да је успостави на јулијевској сахрани, јавно легитимише и тако себе представи као човека који, између осталог, баштини макар део популарског програма. Уколико би се отишло корак даље па рекло да је Цезар представио себе као „неку врсту Маријевог наследника”, 32 занемарили бисмо не само Цезарову амбициозност, већ и оригиналност и снагу његовог покрета.

Потресеност плебса - у ствари Маријевих ветерана - што је на Капитолу заблистала статуа њиховог јунака, када се успомена на Марија заиста оживљавала у јавности, јесте и сведочанство њихове оданости Марију. Истовремено, на основу ове епизоде може се потврдити да је сећање на њега било не само потиснуто, већ да није ни постојало у јавном животу: ${ }^{33}$ ветерани су заплакали зато што је коначно, после толико година, одато јавно поштовање њиховом војсковођи. Маријеве присталице нису могле саме да оставе трага својих емоција нити да маријевски популарски програм учине присутним у јавном животу; били су то стари и заборављени људи и живели су у времену када су се осећали ефекти Сулиног покушаја да ограничи утицај популарских ветерана и њихове везаности за војсковођу на римску политику. ${ }^{34}$ Ветерани

28 Викторија је притом приказана како носи трофеје, а Цезар је обновио и натпис који је обележавао Маријеву победу над Кимбрима. Упор. Plut. Caes. 6.1-2; видети и Vell. 2.43.4; Prop. 3.11.46. Светоније (Caes. 11) у овом контексту пише и о Цезаровом говору против оних који су за новац достављали у време проскрипција (упор. Pelling (нап. 27), 158). Тиме је лакше објаснити Цезаров успех. Види и цезаровску интонацију код Проперција (2.1.24): Cimbrorumque minas et benefacta Mari).

${ }^{29}$ E. Badian, From Iulii to Caesar, y: A Companion to Iulius Caesar, ed. M. Griffin, Malden $2009,15$.

30 Упор. L. Ross Taylor, “The Rise of Julius Caesar”, Greece \& Rome 4/1(1957), 14-15; H. van der Blom, Cicero's Role Models. The Political Strategy of Newcomers, Oxford 2010, 191. Циљ овог чланка није анализа даљих Цезарових планова. Као што је познато, Цезара су његови непријатељи оптуживали да је, утврђујући свој престиж и стављајући се на чело популара, „спремао тиранију”, тј. „изигравао револуционара” (Plut. Caes. 6.3).

31 Гај Јулије Цезар Страбон као један од децемвира: Broughton $M R R$, III, 109; упор. Badian (нап. 29), 15-16.

32 G. S. Sumi, Ceremony and Power. Performing Politics in Rome between Republic and Empire, Ann Arbor 2005, 44.

33 Успомена на Марија била је потиснута због раширеног страха, а не формално забрањена (упор. Pelling (нап. 27) 151), како мисли Н. I. Flower, Ancestor Masks and Aristocratic Power in Roman Culture, Oxford 1996, 103, па основу тога што је Марије био проглашен за hostis publicus (i.a. Liv. Per. 77; App. BCiv. 1.60; Nep. Att. 2.2; Val. Max. 3.8.5; упор. P. Jal, “"Hostis (Publicus)» dans la littérature latine de la fin de la République”, REA 65(1963), 55).

34 Badian (нап. 2), 23. 
великих војсковођа нису били важан политички фактор током седамдесетих и шездесетих година, као што су то постали касније.

Цезар је закључио - у времену када популарски програм није могао бити довољно искоришћен - да успомена на Марија може помоћи његовом политичком успону. Тако је овај Помпејев пријатељ један умртвљени, заборављени популарски симбол везао за себе, за своју каријеру. Успомена на Марија током шездесетих година заправо је цезаровска манифестација, цезаровска до те мере да се везује за Цезара лично. Отуда о Цезаровој маријевској манифестацији тако можемо читати само у Плутарховој биографији, док је - рецимо - Апијан уопште не спомиње.

III. Низ сведочанстава о наводној (аргументи са претходних страница, верујем, дозвољавају да се употреби та реч) Маријевој постумној популарности потиче од Цицерона, који је имао своје личне и политичке разлоге да о Марију пише и говори у позитивном тону: ${ }^{35}$ у питању је заједничка patria, Arpinum, ${ }^{36}$ novitas, ${ }^{37}$ као и фамилијарна повезаност преко једне предачке женидбе. ${ }^{38}$ О Марију Цицерон говори и пише као о великом римском војсковођи, у рангу Сципиона Афричког, Фабија Максима и Марцела. ${ }^{39}$ Марије је за Цицерона „отац отаџбине”, ,спаситељ отаџбине” и сл., ${ }^{40}$ херој који је оправдано и легално погубио народног трибуна Луција Апулеја Сатурнина. ${ }^{41}$ Каткада Цицерон само реферише на Марија у позитивном смислу. ${ }^{42}$

35 Главна студија о овоме питању остаје и после шездесет година: T. F. Carney, “Cicero’s Picture of Marius", WS 73 (1960), 83-122, али треба имати у виду и примедбу коју износи Santangelo, "Cicero and Marius", Athenaeum 96 (2008), 597: somewhat chaotic article.

36 Cic. Sest. 37; 50.

37 Марије је био, као и Цицерон, Арпињанин и homo novus, видети Mur. 17; Sull. 23; упор. Van der Blom (нап. 30), 188-189. По Цицерону, homines novi поседују марљивост (industria) и врлину (virtus), за разлику од декадентних нобила (Cluent. 111-112; Scaur. fr. 1.4; Verr. 2.3.7; 2.5.180-182; Sull. 23; Mur. 15-17; Sest. 136-137; упор. Van der Blom [нап. 30], 49-51). Уз то Маријева каријера је, уз Катонову, утрла пут другим људима истог социјалног статуса, укључујући Цицерона: Verr. 2.5.181. Дакле, када је у питању novitas, Марије представља лични пример за Цицерона (упор. Van der Blom [нап. 30], 182), обојица су као homines novi спасили Рим: Sull. 23; Post Red. Quir. 9; Leg. 2.26. Али, Цицерон никада није био сноб, за разлику од Марија (упор. Badian [нап. 2], 7).

38 Притом, женидбена повезаност Тулија Цицерона и Марија преко фамилије Гратидија (Cic. Brut. 168; упор. Fr. Münzer, $R E$ 14, 1825 sqq: Марко Гратидије се оженио Маријевом сестром, док је Гратидијева сестра била жена Цицероновог деде) била је још један разлог за Цицерона да гаји личну наклоност према Гају Марију. Упор. Van der Blom (нап. 30), 181-182, као и сведочанство да је псеудо-Марије тражио помоћ на суду од Цицерона, позивајући се на фамилијарне везе са њим (Att. 12.49 (SB 292).2). $184-185$.

39 Man. 47; 60; Verr. 2.3.209; 2.5.14; Cat. 4.21-23; упор. Van der Blom (нап. 30), 181-182;

40 Sest. 37: conservator patriae; Sest. 38: spes subsidiumque patriae; Sest. 116: conservator huius imperii; Post Red. Quir. 9: custos civitatis atque imperii vestri; упор. Sest. 50: Маријево бекство је ad salutem huius imperii.

41 Rab. Perd. 21, 27, 29, 30; Маријева одлука да то учини није донета лако: први пут у римској историји senatus consultum ultimum био је искориштен ради обрачуна са римским магистратом. То ће поновити Цицерон 63. године; упор. Badian (нап. 17), 118-119. Уосталом, Цицерон отворено каже да би он исто поступио као и Марије: Rab. Perd. 35; упор. A. Lintott, Cicero as Evidence. A Historian's Companion, Oxford 2008, 122-123.

42 Hпр. Pis. 20, иако је овде био у прилици да контрастира Маријеву ратоборност према Метеловом мирољубивом самопожртвовању. На другом месту Цицерон говори о Маријевој врхунској трезвености, лукавости Att. 10.8 (199 SB). 7 (callidissimus); додуше, упркос 
Цицерон на више места у свом опусу спомиње Маријево изгнанство. Изгледа да је та епизода из његовог живота имала важно место у Mapujy, насталом, како се чини, баш педесетих година, када је Цицерон, због сопственог изгнанства, посебну пажњу поклањао овом егземпелу. ${ }^{43}$ Причу о Маријевом изгнанству Цицерон је чуо од самог војсковође, са свим колоритним детаљима као што је дављење у мочвари код Минтурне или као што је бекство пред прогонитељима у малом чамцу све до Африке. ${ }^{44}$ Цицерон спомиње Маријево страдање најчешће како би се његово изгнанство могло довести у везу са сопственим, али уз наглашавање да је његов повратак био славнији и достојнији од Маријевог. ${ }^{45}$ Или, један од разлога поменутог оправдавања Маријевог убиства Сатурнина био је у томе да се афирмише сопствена одлука да, када је био у прилици и у сличној ситуацији, дакле, када је поседовао право да употреби senatus consultum ultimum, ипак одбије да се Катилина убије, иако би таква одлука, како каже, била потпуно оправдана. ${ }^{46}$

Тешко би било тврдити да је Цицеронова политичка потреба - повезана са његовим сентименталним и личним разлозима обојеним разумевањем за скромног витеза из Арпинума ${ }^{47}$ који постаје вишеструки конзул - наилазила на одобравање међу нобилитетом, као и да уопште није подразумевала известан ризик. Цицерон је сигурно био тога свестан, па је чак и гледао да се огради од Марија. То је по правилу чинио пред Сенатом или колегијем

тој способности, он није успео да предвиди Сулин марш на Рим; упор. J. van Ooteghem, Caius Marius, Bruxelles 1964, 27. Omnium perfidiosissimus (Nat. Deor. 3.80) што би било друго, негативно лице његове трезвености које треба најпре разумети као схватање учесника у дијалогу, чије су то речи и биле. Дакле, овде се ради о рђвом суду о Марију из уста његовог непријатеља, Аурелија Коте, а није у питању Цицеронова негативна оцена Маријевог карактера (другачије, Syme [нап. 13], 163 sq).

43 Као што се чини на основу четрнаест стихова из једног од два навода из спева (Cic. Div. 1.106): R. Gnauk, Bedeutung des Marius und Cato Maior fuer Cicero, Ebering 1935, 49-60; упор. E. Courtney (ed. with comm.), Fragmentary Latin Poets, Oxford 1993, 175; L. P. Kenter, M. Tullius Cicero, De Legibus. A commentary on book I, Amsterdam 1972, 21-22; A. R. Dyck, A Commentary on Cicero, De Legibus, Ann Arbor 2004, 57-58; Santangelo (нап. 35), 598-599.

${ }_{44}$ Post Red. Quir. 20; Sest. 50; у скраћеној верзији: Pis. 43; Planc. 26. Упор. Lintott (нап. 41), 216-217.

45 Rep. 1.6 (само се спомиње Маријево прогонство, заједно са Камиловим, Ахалиним, Назикиним, Метеловим, Опијевим, прогонством Попилија Лената). Div. 2.140-142: Марија доводи у везу са собом пошто се он са храброшћу држао када је био прогнан.

${ }^{46}$ Cic. Cat. 1.4: Simili senatus consulto C. Mario et L. Valerio consulibus est permissa res publica; num unum diem postea L. Saturninum tribunum pl. et C. Servilium praetorem mors ac rei publicae poena remorata est? At [vero] nos vicesimum iam diem patimur hebescere aciem horum auctoritatis. Habemus enim huiusce modi senatus consultum, verum inclusum in tabulis tamquam in vagina reconditum, quo ex senatus consulto confestim te interfectum esse, Catilina, convenit. Упор. А. А. Maclardy (ed. transl, comm.), The First oration of Cicero against Catiline, New York 1902, 39, comm. ad lin. 17. Без обзира на то што је Pro Rabirio објављен после 63. године (упор. Att. 2.1 [SB 21].3) Lintott (нап. 41), 124 сматра да је Цицеронова одбрана институције senatus consultum ultimum везана за 100. годину, а не за његове поступке у време Катилинине завере, иако и сам увиђа да је Цицерон назвао Сатурнина непријатељем државе (hostis; Rab. Perd. 18), што су били и завереници из децембра 63. године. Уз то, страдале Катилинине присталице били су магистрати, управо као и Сатурнин и Глауција. Притом, Линтот се не осврће на ову цитирану реченицу, која сведочи да је своје неостварено право да још раније нареди Катилинино убиство Цицерон заснивао на догађајима из Маријевог и Валеријевог конзулата.

${ }^{47}$ Cic. Tusc. 2.53: Rusticanus vir, sed plane. 
понтифика, не либећи се да буде и критичан, док је у говорима пред народом, очекиваним маријевским присталицама, претежна је оцена у литератури, контекст у којем се спомиње Марије махом позитиван. ${ }^{48}$ Слично је Цицерон умео да, пред народом и у судници, повољно говори и о браћи Грах, свестан да ће тиме учврстити свој положај код плебса, али и да их оцени као опасне демагоге пред Сенатом или у теоријским списима, стављајући их чак у исту раван са Сатурнином. ${ }^{49}$

Али, има и важних одступања од овог модела у Маријевом случају. Отуда, нпр. када у Post Reditum ad Quirites (одржаном почетком августа 57. године) пореди сопствено и Маријево изгнанство, називајући Марија најхрабријим од свих људи, Цицерон одмах подвлачи разлику између њих двојице, будући да ce Марије, animo irato, осветио својим непријатељима, док се он сам, након повратка из прогонства, служио искључиво речима. Маријева мотивација је доведена, штавише, у јасну опозицују према pax atque otium, Цицероновом циљу. 50 Цицеронова поента није у супротности са оним што је рекао неколико месеци раније у говору пред Сенатом, с тим што је питање његовог и Маријевог односа према Сенату стављен у први план: својим повратком Марије умало није уништио Сенат, док је Цицерон посвећен очувању власти Сената. ${ }^{51}$

Неколико месеци касније, у Pro Sestio, дакле пред широком публиком, Цицерон продубљује ово разилажење са Маријем. Марије је, каже Цицерон, вративши се из прогонства, гледао како да се освети, док се он, Цицерон, након повратка посветио очувању државе. ${ }^{52}$ И касније, пред крај живота, нарочито у време грађанских ратова, Цицерон је у говорима „пред народом” износио неповољан суд о Марију, 53 с тим што су његове примедбе ту биле готово успутне. Марије је био у центру његовог интересовања током прогонства и непосредно после повратка из прогонства ${ }^{54}$ када је могао поредити

48 E. Rawson, "Lucius Crassus and Cicero: the formation of the statesman", PClPhS 17 (1971), 76-79; D. Mack, Senatsreden und Volksreden bei Cicero, Würzburg 1937, 26-27, 34-35; F. Bücher, Verargmentierte Geschichte. Exempla Romana in Politischen Diskurs der Späten Republik, Stuttgart 2006, 248-249; C. E. Thompson, To the Senate and to the People: addaptation to the senatorial and popular audiences in the parallel speeches of Cicero, diss Ohio State University, Columbus 1978, 101-103.

49 Пред народом позитивно: е. g. Leg. Agr. 2.10; 2.31; 2.81; Rab. Perd. 12-15; Font. 39; Cluent. 151; Пред Сенатом негативно: е. g. Leg. Agr. 1.21; Cat. 1.3-4, 4.4; 4.13; Har. Resp. 41, 43; Prov. Cons. 18; Phil. 8.13; Caes. 87. У теоријским списима негативно: Rep. 3.41; Leg. 3.20-2; Off. 2.72; Fin. 4.65; Tusc. 3.48; Lael. 38-40, одајући им признање, додуше, да су били добри говорници (Brut. 103-4, 125-6; De Or. 1.38). Довођење у везу Граха и Сатурнина видети у референцама код Van der Blom (нап. 30), 107, нап. 113. Упор. J. Béranger, "Les jugements de Cicéron sur les Gracques", $A N R W 1.1$ (1972), 732-763; Van der Blom (нап. 30), 104-107.

50 Post Red. Quir. 19-21; упор. Van der Blom (нап. 30), 204; Santangelo (нап. 35), 600; Lintott (нап. 41), 12-13. О славном Цицероновом повратку упоређеном са мање славним Маријевим види још и Dom. 82; 87; Post Red. Sen. 37-38.

51 Post Red. Sen. 38; упор. Santangelo (нап. 35), 599.

52 Sest. 50; упор. Van der Blom (нап. 30), 205; Carney (нап. 35), 112-113; R. A. Kaster (transl. with intr. and comm.), Cicero. Speech on Behalf of Publius Sestius, Oxford 2006, 233.

53 Phil. 11.1: C. Marius in iracundia perseverans. 13.1: Marius ... civile bellum optavit; Ooteghem (нап. 42), 26; упор. Phil. 8.7 - ту Цицерон каже да је разлог избијања грађанских ратова политичка свађа, помињући именом Марија у неповољном контексту.

${ }^{54}$ Cic. Div. 2.140: ut mihi temporibus illius (време прогонства) multum in animo Marius versabatur recordanti... 
сопствено изгнанство са његовим и када је могао поентирати о сопственој мирољубивости, државотворности (повратак уз консензус свих, народа, $\mathrm{Ce}$ ната, целе Италије) и контрастирати своју благост и помирљивост према Маријевом крвавом осветничком пиру над пораженим непријатељима. ${ }^{55}$

Сме се рећи да из Цицеронових сведочанстава о Гају Марију не треба очекивати савршено конзистентну слику, а свакако их треба тумачити одавно је познато - у контексту Цицеронових савремених политичких преокупација. Тако су Цицеронове реминисценције на Марија током шездесетих година кратке, у основи повољне, где се хвали његово војничко умеће или брани његово поступање 100 . године; ${ }^{56}$ но, похвале Марију нису интониране тако - ни у мери ни у облику - да би се могло рећи да се Цицерон изложио политичком ризику да буде препознат као маријевац.

Током прве половине педесетих година, у време након прогонства, пак, Марије се у говорима пореди а некада и контрастира према самом Цицерону. Стога су поједине епизоде из Маријевог живота употребљаване заиста као примери из прошлости, ${ }^{57}$ а нарочито да би се Цицероново деловање представило у што повољнијем светлу. Тако узев, Цицеронови маријевски примери пре сведоче да би се сећање на њега могло лично и политички употребити, слично као што је то Цезар учинио током шездесетих, него што је у питању доказ да је у римском друштву - ван света Маријевих ветерана остало живо, стварно сећање на Гаја Марија, спаситеља отаџбине и вођу популарске странке.

Заправо, било би тешко замислити да би се о Гају Марију, окруженом толиким непријатељима за живота, ${ }^{58}$ Марију који је издао популарску ствар спречивши Сатурнинов преврат, Марију који је поражен у Грађанском рату који је сам изазвао и потом окрвавио руке, могла сачувати недвосмислено повољна успомена. Код Цицерона, осим поменутих осуда суровости Маријевог режима у Филийикама, 59 у приватном писму, сроченом у марту 49. године, када је разматрао да ли треба да напусти Италију пошто је Цезар започео Грађански рат, каже да је Маријев (и Цинин) режим (уз Сулин) био најсуровији и најзлобнији у читавој римској историји, ${ }^{60}$ да би, поново пред крај живота, оставио потресно сведочанство о Маријевој нелојалности и суровости. ${ }^{61}$ Те Цицеронове речи су заправо у складу са претежним оценама у римској историографији о карактеру Гаја Марија. Марија).

55 Видети још и Post Red. Quir. 10 (под „они” Цицерон мисли на Попилија, Метела и

56 E. g. Font. 36; 43; Rab. Perd. 21; 29; Verr. 3.209; 5.14; 5.25; 5.181; Leg. Man. 47; Arch. 5; 19; Cat.1.4; 3.15; 2.24; Mur. 17; Sull. 23.

57 У дословном смислу дефиниције појма exemplum: „Кратка прича, анегдота или историјски догађај испричани зато да поткрепе неку моралну поуку или илуструју мисао" (J. Deretić, s. v. "Egzempel”, u: Rečnik kniževnih termina, Beograd 1986, 156).

${ }_{58}$ Cic. Prov. Cons. 19: Quis plenior inimicorum fuit C. Marius?

59 Види горе, напомена 53.

60 Att. 9.10 (177 SB).3: sed quid eorum [at Sulla, at Marius at Cinna] victoria crudelius, quid funestrius?

61 Tusc. 5.56; Марије је неколико пута изговорио moriatur када су Катулови пријатељи замолили да поштеди живот човеку с којим није био само савезник, конзул и тријумфатор већ и пријатељ који му је умногоме помогао. Упор. Cic. Nat. Deor. 3.80; Brut. 307; De Or. 3.9; Plut. Mar. 44.8; Diod. 38.4.2-3. 
Да закључим. Након завршетка грађанских ратова није само Сулина диктатура гушила сећање на Гаја Марија, него ни вође покрета против оптиматског режима нису посезале за Маријевим ликом, пре свега због суровости која се везивала за његово име. Будући да је сећање на Марија било готово мртво или угушено неповољним оценама у историографији или политичкој аутобиографији, када је Јулије Цезар почео да оживљава успомену на њега, он је тој успомени могао безмало давати садржај који му је одговарао. Захваљујући Цезару, тј. његовој процени да му је таква слика о Марију потребна, Марије се у јавном сећању појављује као вођа популарске странке, као да није било чувене издаје из 100. године. Притом, макар у почетку, успомена на Марија крчила је пут зато што је то била и јулијевска манифестација, будући да су Маријеви ветерани много дуговали и Цезаровом оцу, једном од чланова комисије за доделу земље. Неколико година после Цезара Цицерон је, у вези са сопственим наративом о неоправедном изгнанству и славном повратку, створио, претежно у говорима, представу о Марију као о протераном спасиоцу отаџбине, као да том протеривању нису претходиле сурове егзекуције које је Марије починио, подстакао или одобрио. Маријево изгнанство Цицерон је призивао у сећање како би сопствено политичко деловање представио у што повољнијем светлу. Али, уверен сам да овакве цезаровско-цицероновске преформулације Маријеве биографије - преформулације које је Цицерон пред крај живота заправо негирао понављајући оцене о Маријевој суровости и одговорности за Грађански рат - не би биле могуће да се нису заснивале на истини, макар селективној: Гај Марије јесте био човек који је после смрти Гаја Граха поново подигао популарски покрет и јесте био спасилац Италије и Рима од варварског мача. Али, не само то.

ORIGINAL SCIENTIFIC PAPER

Prof. ŽARKO PETKOVIĆ, PhD

University of Belgrade

Faculty of Philosophy

Department of History

zarkopetkovic@gmail.com

\section{THE POSTHUMOUS POPULARITY OF C. MARIUS}

SUMMARY: The idea of the posthumous popularity of C. Marius has never been seriously challenged. However, the lack of evidence that the memory of Marius influenced politics in Rome twenty years (or so) after his death, should be the first indication that the deeply rooted picture of Marius as saviour of the fatherland and leader of pupulares did not in fact exist, at least during the seventies and the first half of the sixties. In fact, the public memory of Marius emerged later, when Caesar and Cicero were motivated to launch the narrative of Marius as a popular leader, the general who saved Italy and the victim of Sulla, the dictator. Caesar took the opportunity to use his aunt's funeral as a Marian and popular manifestation, as described by Plutarch. Nevertheless, that manifestation may have been less Marian and more Iulian, bearing in mind that veterans of the old general had a special reason to be grateful to 
Caesar's father who was one of the decemviri in charge of land distribution. In fact, the introduction of Marius' imago on that occasion was the first public expression of popular and Marian sentiment, more than twenty years after Marius' death, when the image of Caesar as a popular leader was taking its shape. On the other hand, a few years later, Cicero proclaimed from the rostra that Marius was pater patriae, saviour of the fatherland who had courageously defeated not only the northern barbarians but also the radical tribune Saturninus, who seriously threatened the Republic. Despite the fact that Cicero had some consideration for Marius as homo novus and Arpinatus, it was not his intention simply to revive the sentimental memory of defeated Marius. Cicero's narrative of Marius in the first half of the fifties was dedicated to the last years of general's life, above all his exile and victorious return. This and other Ciceronian Marian exempla, clearly served to magnify the picture of Cicero himself. But he also distanced himself from Marius: for example, the return of Cicero from exile brought peace and glory to the Commonwealth unlike Marius' return which led to the Civil War and extensive bloodshed. Additionally, open critiques of Marius can easily be found in Cicero's oeuvres, and not just in the speeches delivered to the patres, as is commonly supposed. His attitude towards Marius seems more negative than has previously been supposed: even in the speeches made before the people, Cicero's critique of Marius can be detected. When the grand theme of his exile was of less immediate import, Cicero's assessment of Marius - not only in the Philippics, but also in his philosophical treatises and in the letters - approaches the expression of Periocha of Marius as seditionis auctor. This brings Cicero's understanding of Marius' legacy more into line with that of contemporary Roman historiography, which was openly hostile to the general, as Plutarch recorded.

KEYWORDS: The end of Roman Republic, C. Marius, C. Iulius Caesar, M. Tullius Cicero, populares, Roman historiography 